\title{
Lead Fractures after Vagal Nerve Stimulator Implantation
}

\author{
Vagal Sinir Stimülatörü İmplantasyonu \\ Sonrası Görülen Lead Kırıkları
}

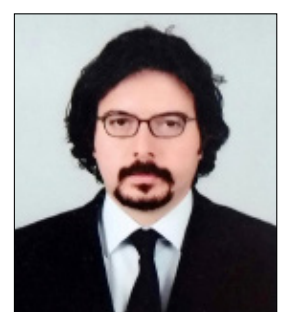

Dr. Ahmet Eren SEÇEN

\section{(1) Ahmet Eren SEÇEN, ${ }^{1}$ • Ayfer ASLAN, ${ }^{2}$ ๑b Erkut Baha BULDUK, ${ }^{3}$

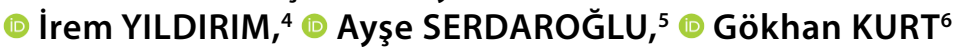

'Department of Neurosurgery, University of Health Sciences, Fatih Sultan Mehmet Training and Research Hospital, İstanbul, Turkey

2Department of Neurosurgery, Şırnak State Hospital, Şırnak, Turkey

${ }^{3}$ Department of Neurosurgery, Eskişehir State Hospital, Eskişehir, Turkey

${ }^{4}$ Department of Neurology, Gazi University Faculty of Medicine, Ankara, Turkey

${ }^{5}$ Department of Pediatric Neurology, Gazi University Faculty of Medicine, Ankara, Turkey

${ }^{6}$ Department of Neurosurgery, Gazi University Faculty of Medicine, Ankara, Turkey

\section{Summary}

Objectives: Vagal nerve stimulator is an effective treatment option for the medical treatment of the resistant-epilepsies. Surgical complication risks, as well as device-dependent risks, are also present. In this study, we aimed to draw attention to lead fractures from device-dependent complications.

Methods: Between March 2005 and March 2015, patients who had vagal nerve stimulator implantation were screened in our clinic, and patients with lead fractures were included in this study.

Results: Vagal nerve stimulator implants were implanted to over 170 patients in our clinic, and 11 of them were found to have lead fractures. They were all taken to revision surgery.

Conclusion: Although lead fractures are not common, they form $11 \%$ of the device-dependent complications. High seizure severity, frequent frequency, long seizures and trauma may cause lead fractures.

Keywords: Complication; lead fractures; vagus nerve stimulator.

Özet

Amaç: Vagal sinir stimülatörü, tıbbi tedaviye dirençli epilepsilerde kullanılan etkin bir tedavi seçeneğidir. Cerrahi komplikasyon riskleri olduğu gibi cihaza bağımlı riskleri de mevcuttur. Bu çalışmamızda, cihaz bağımlı komplikasyonlardan lead kırıklarına dikkat çekmeyi amaçladık.

Gereç ve Yöntem: Mart 2005-Mart 2015 tarihleri arasında kliniğimizde vagal sinir stimülatörü implantasyonu yapılan hastalar tarandı ve hastalardan lead kırıkları olanlar bu çalışmaya dahil edildi.

Bulgular: Kliniğimizde 170'in üzerinde hastaya vagal sinir stimülatörü implantasyonu yapılmış olup bunların 11 tanesinde lead kırığı saptandı. Hepsi revizyon cerrahisine alındı.

Sonuç: Lead kırıkları çok sık görülmese de cihaz bağımlı komplikasyonların \%11'ini oluşturmaktadır. Nöbet şiddetinin yüksek, frekansının sık olması, nöbetlerin uzun sürmesi ve travmalar bu kırıklara neden olabilmektedir.

Anahtar sözcükler: Komplikasyon; lead kırıkları; vagus sinir stimülatörü.

(C) 2019 Turkish Epilepsy Society
Submitted (Geliş): 02.10.2018

Accepted (Kabul) : 18.12.2018

Correspondence (illetişim): Erkut Baha BULDUK, M.D. e-mail (e-posta): erkutbahabulduk@hotmail.com 


\section{Introduction}

Epilepsy is a chronic neurological disorder most commonly seen in the world due to uncontrolled neural stimulation in the brain. When the antiepileptic drugs cannot control the seizures, surgical treatment options are considered. ${ }^{[1,2]}$

Vagus nerve stimulation, which was first investigated since the beginning of the $20^{\text {th }}$ century and later as a potential treatment for epilepsy, has been considered an effective seizure control tool in patients with persistent epileptic since the early days. Tournade and Malméjac (1929) found that the tremor that arose from cooling was inhibited by stimulating the nerves of the Hering (a branch of the nervus glossopharyngeus). Then, Koch (1932) found out that the spontaneous movements were blocked after the increasing pressure on the carotid sinus.

The different results obtained by Danielopolu and colleagues $(1931,1932,1933)$ indicated that following local strenction of the motor cortex, epileptiform seizures might be induced by baroseptic or afferent vagopathic-depressor stimulation. ${ }^{[3-5]} A$ series of experiments conducted by Zabara showed that vagus nerve stimulation could be used to stop experimentally induced seizures in dogs. ${ }^{[6]}$ These findings first led to the development of a commercial VNS device that was clinically implanted in 1988 by Penry et al. ${ }^{[7,8]}$

Vagus nerve stimulation (VNS) is therapy available in the treatment of resistant epilepsy in Europe in 1994 and the United States in 1997, following phase 1, phase 2 and phase 3 trials conducted by the First International Vagus Nerve Stimulation Study Group in 1994. ${ }^{[9-11]}$ VNS was approved in 2001 in Europe and in 2005 in the US for the depression treatment. In the last two decades, vagus nerve stimulation (VNS) has become an acceptable and viable treatment model for both epilepsy and childhood resistant epilepsy. ${ }^{[12]}$ Compared with other neurosurgical interventions surgically removed from the seizure focus, VNS offers a lower-risk operation with fewer complications.

Surgery involves the placement of helical electrodes on the left cervical vagus nerve, with intermittent stimulation provided by a neurocybernetic prosthesis implanted subcutaneously in the upper chest. The stimulating parameters change; however, studies suggest that maximum protec- tion from seizures can be achieved with stimuli periodically given at $20-30 \mathrm{~Hz}$. Most of the patients are now being stimulated at $30 \mathrm{~Hz}$ with a constant stimulus cycle for 30 seconds and closed for five minutes.

Although the mechanism of action is not fully understood, various studies in the relevant literature suggest that the activation of vagal afferents through electrical stimulation of the VNS directly and indirectly affects the seizure-associated cycle in the brain. VNS changes cerebral electrical activity via thalamocortical pathways. ${ }^{[8,13]}$ Secondary afferent and efferent currents to VNS stimuli are responsible for short and long-term effects. While the afferent stimulation is thought to arise from the parasympathetic outflow from the solitary tract, current data have shown that efferent fibers may also lead to increased serotonin and epinephrine release as long-term effects of VNS. ${ }^{[14-16]}$

Complications in the use of VNS can be classified as complications of operation complications and VNS effects. As operative complications, carotid artery, jugular vein, vagus sinus injuries, clavicle injury, esophageal injury, pneumothorax, peritracheal hematoma, wound infection can be listed; arrhythmia, asystole, bradycardia can be counted during the initial VNS stimulation.

After VNS activation after the operation, cough, sore throat, aphonia, difficulty in breathing, chest pain may be seen. ${ }^{[17,18]}$ Other complications related to hardware include lead fracture, system breakage, spontaneous closure, and impairment of the stimulator. ${ }^{[18]}$ Despite the use of VNS for more than 20 years, the debate on security and effectiveness still continues. ${ }^{\text {[12] }}$ Our center started to implant VNS in 2005 and continued to implant every year with a steady number of operations.

\section{Materials and Methods}

In this study, all patients undergoing surgery in this case series were medical treatment-resistant epilepsy patients with different etiologies and syndromes. Patients' epilepsy, which was resistant to medication, regardless of the syndrome, was taken to surgery after being evaluated by a multidisciplinary epilepsy team at Gazi University Medical Faculty Hospital, Ankara. All the cases in this study were operated by only the same neurosurgeon (GK). Patients who underwent VNS implantation for resistant epilepsy from March 2005 to March 2018 were retrospectively identified from the Epilepsy Center data. Among the patients who un- 


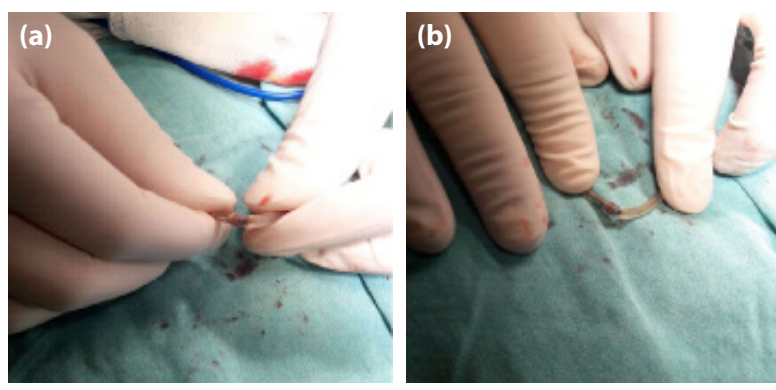

Fig. 1. (a, b) The fracture site of the vagal nerve stimulator removed by surgical is clearly seen.

derwent revision surgery and who had lead fractures were included in this study.

\section{Results}

In this study, over 170 patients were implanted with VNS implants. One patient was predominantly implanted with a VNS device (VNS Therapy Cyberonics ${ }^{\circledR}$ Inc. Houston TX U.S.A) for epilepsy with a history of drug-resistant epilepsy. Lead fractures were encountered in 11 (6.5\%) of the patients in follow-up (Figb 1a, b). All of the 11 patients underwent surgical revision. Examinations were administered during and after the revision revealed macro fractures in four patients and micro fractures in seven patients. Only three of the patients had a trauma-like history. Eight of the patients were patients with the old generator attached.

\section{Discussion}

VNS is a proven form of reliable treatment that has been available since the years of the 1990s. Given the increased use of VNS in the treatment of medical treatment-resistant epilepsy and the new and potentially additive indications, the incidence of VNS lead disorders will likely to continue to increase. ${ }^{[12,15,19]}$ The most common cause of VNS failure is the end of battery life. Depending on the pulse width, frequency and lead impedance, the battery life varies from four to ten years. ${ }^{[20]}$

Lead disorders usually arise from tears in the silicone seal, or from a complete fracture that occurs spontaneously or after trauma. As it is reported by the Aalbers et al., ${ }^{[22]}$ the deterioration with time causes the tearing in the silicone coating and the complete breakage by the electrical failure, which eventually takes place. Old generators (Model 301, 302) have higher error rates in this regard. Second generation generators 303, 304 are considered to be more resistant to wear in the long run. According to old devices, $7 \%$ and $0.2 \%$ of the surgical revisions are seen in new devices compared to $27 \%$. Patients benefiting from first-generation lead-bearing VNS are at greater risk than patients with a new generation of simulators for lead fractures. ${ }^{[21]}$

Magney et al. ${ }^{[23]}$ asserted that soft tissue compression brings a static load on the lead in the cardiac pacemaker lead fractures and that cyclic costoclavicular compression may cause fractures from this compression zone.

Lead factors depend on many factors, including the identification of the patient's clinical symptoms, seizure frequency and system interrogation, and lead impedance. Especially in the case of high impedance in the VNS lead, the probability of going to revision is increasing. ${ }^{[15]}$ However, a high impedance is not always seen in the lead fracture, microlesions in the cable, and vaginal scar tissue formation is among the factors. ${ }^{[19]}$

Lead fractures are among the mechanical or technical complications in general use. ${ }^{[12,15,19]}$ There are not always visible
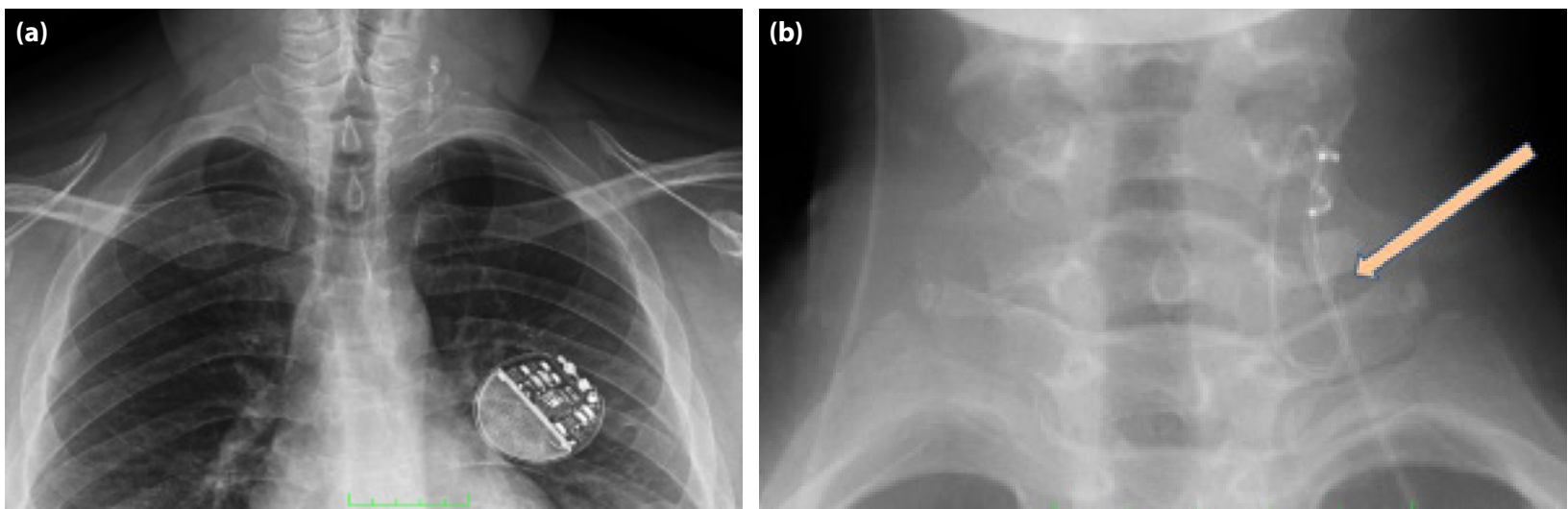

Fig. 2. (a) Pre-operative x-ray image of a lead with a microfracture. (b) Pre-operative x-ray image of a lead with a macrofracture. 
lesions, and it is very common in microfractures, which makes the radiological detection of fractures difficult (Fig. $2 a, b)$.

The most common symptom associated with VNS device insufficiency increased seizure frequency. ${ }^{[15]}$ The lead revision is performed only after the pulse generator has been interrogated, and the system diagnostics are realized (lead test). It is advisable to perform a lead change under two following conditions: 1 - To demonstrate lead absences with $X$ ray, i.e., whether there is mechanical integrity deterioration not and/or 2 - To show lead high or low lead impedance as a result of the lead test. ${ }^{[3]}$

In Dlouhy et al.'s ${ }^{[15]}$ a series of 25 case lead revisions, 16 (64\%) of the 18 patients with high impedance during revision no visible damage or fracture of lead and/or cable were seen. This finding suggests an internal lesion in the lead and/or the cable. Three out of (12\%) of the other nine patients had visible lead fracture, two cases had an impedance showing short circuits (8\%), two cases (8\%) had device failure, one case $(4 \%)$ had electrode coil removed from the vagus nerve one patient had VNS system removal due to a previous infection (4\%). ${ }^{[14]}$ In the study of Espinosa et al., ${ }^{[24]}$ the lead disorder was formed four out of ten revisions. MacDonald ${ }^{[25]}$ showed that one of the seven patients who underwent revision surgery had a lead fracture.

Two major surgical revision series for VNS impairment and infection were reported by Couch ${ }^{[26]}$ and Révész ${ }^{[12]}$ after 14 and 25 years of follow-up. Lead failure was reported in $8 \%$ of the 644 patients reported by Couch ${ }^{[26]}$, and lead malfunction in $3 \%$ of the 247 patients reported by Révész. ${ }^{[12]}$ The Couch has divided the lead disorder into three subheadings. These subgroups are unconfirmed causes concerning cable breakage, insulation breakage, or high lead impedance. ${ }^{[26]}$ In Couch ${ }^{[26]}$ and Révész, ${ }^{[12]}$ one case of surgical cable breakage $(1 \%, 0.2 \%)$ was reported separately. ${ }^{[2]]}$ In the study of Spuck et al., ${ }^{[19]}$ lead fragments were formed in the eight of ten cases considered as technical complications.

\section{Conclusion}

Although lead fractures are not a common complication of general VNS complications, their location cannot be underestimated in complications arising from hardware failures. The approach of our clinic in these cases is to undergo the change process after making sure of the imped- ance measurements from the lead fracture. The lead, which is thought to be broken during the change, should be removed slowly and with microsurgical techniques without damaging the vagus sheath. The system should be replaced as a whole and follow-ups should be continued after the primary surgery. We should note that it is beneficial to make the change process in epilepsy centers with more VNS case experience.

\section{Peer-review}

Externally peer-reviewed.

\section{Conflict of interest}

The authors declare that they have no conflict of interest.

\section{Authorship Contributions}

Concept: A.E.S., A.A.; Design: E.B.B., I.Y.; Supervision: A.S., G.K.; Materials: A.A., E.B.B.; Data collection \&/or processing: A.E.S., I.Y.; Analysis and/or interpretation: A.S., G.K.; Literature search: A.A., I.Y.; Writing: E.B.B., A.E.S.; Critical review: A.S., G.K.

\section{References}

1. Bulduk EB, Kurt G, Barun $S$, Aydemir O, Kiziltas $M$, Oktem $M$, et al. The Effects of Minocycline on the Hippocampus in LithiumPilocarpine Induced Status Epilepticus in Rat: Relations with Microglial/Astrocytic Activation and Serum S100B Level. Turk Neurosurg 2019;29(1):95-105. [CrossRef]

2. Öcal Ö, Çeltikçi $E$, Seçen $A E$, Bulduk EB, Kurt G. Surgery in Extratemporal Epilepsy. [Article in Turkish]. Türk Nöroşirürji Derg 2014;24:124-9.

3. Waseem H, Raffa SJ, Benbadis SR, Vale FL. Lead revision surgery for vagus nerve stimulation in epilepsy: outcomes and efficacy. Epilepsy Behav 2014;31:110-3. [CrossRef]

4. Zanchetti A, Wang SC, Moruzzi G. The effect of vagal afferent stimulation on the EEG pattern of the cat. Electroencephalogr Clin Neurophysiol 1952;4(3):357-61. [CrossRef]

5. Bailey, Percival and Bremer F. A sensory cortical representation of the vagus nerve: with a note on the effects of low blood pressure on the cortical electrogram. J Neurophysiol 1938;1(5):405-11. [CrossRef]

6. Zabara J. Inhibition of experimental seizures in canines by repetitive vagal stimulation. Epilepsia 1992;33(6):1005-12.

7. Penry JK, Dean JC. Prevention of intractable partial seizures by intermittent vagal stimulation in humans: preliminary results. Epilepsia 1990;31:S40-3. [CrossRef]

8. Krahl SE. Vagus nerve stimulation for epilepsy: A review of the peripheral mechanisms. Surg Neurol Int 2012;3(1):S47-52.

9. Ben-Menachem E, Mañon-Espaillat R, Ristanovic R, Wilder BJ, Stefan $\mathrm{H}$, Mirza W, et al. Vagus nerve stimulation for treatment of partial seizures: 1. A controlled study of effect on seizures. First International Vagus Nerve Stimulation Study Group. Epilepsia 1994;35(3):616-26. [CrossRef] 
10. Ramsay RE, Uthman BM, Augustinsson LE, Upton AR, Naritoku D, Willis J, et al. Vagus nerve stimulation for treatment of partial seizures: 2. Safety, side effects, and tolerability. First International Vagus Nerve Stimulation Study Group. Epilepsia 1994;35(3):627-36. [CrossRef]

11. George R, Salinsky M, Kuzniecky R, Rosenfeld W, Bergen D, Tarver WB, et al. Vagus nerve stimulation for treatment of partial seizures: 3. Long-term follow-up on first 67 patients exiting a controlled study. First International Vagus Nerve Stimulation Study Group. Epilepsia 1994;35(3):637-43. [CrossRef]

12. Révész $D$, Rydenhag $B$, Ben-Menachem E. Complications and safety of vagus nerve stimulation: 25 years of experience at a single center. J Neurosurg Pediatr 2016;18(1):97-104. [CrossRef]

13. Lulic D, Ahmadian A, Baaj AA, Benbadis SR, Vale FL. Vagus nerve stimulation. Neurosurg Focus 2009;27(3):E5. [CrossRef]

14. Hirfanoglu T, Serdaroglu A, Cetin I, Kurt G, Capraz IY, Ekici F, et al. Effects of vagus nerve stimulation on heart rate variability in children with epilepsy. Epilepsy Behav 2018;81:33-40. [CrossRef]

15. Dlouhy BJ, Viljoen SV, Kung DK, Vogel TW, Granner MA, Howard MA 3rd et al. Vagus nerve stimulation after lead revision. Neurosurg Focus 2012;32(3):E11. [CrossRef]

16. Krahl SE, Clark KB. Vagus nerve stimulation for epilepsy: A review of central mechanisms. Surg Neurol Int 2012;3(4):S255-9.

17. Smyth MD, Tubbs RS, Bebin EM, Grabb PA, Blount JP. Complications of chronic vagus nerve stimulation for epilepsy in children. J Neurosurg 2003;99(3):500-3. [CrossRef]

18. Kahlow $\mathrm{H}$, Olivecrona $\mathrm{M}$. Complications of vagal nerve stimulation for drug-resistant epilepsy: a single center longitudinal study of 143 patients. Seizure 2013;22(10):827-33. [CrossRef]

19. Spuck S, Tronnier V, Orosz I, Schönweiler R, Sepehrnia A, Nowak $\mathrm{G}$ et al. Operative and technical complications of vagus nerve stimulator implantation. Neurosurgery 2010;67(2):489-94.

20. D'Agostino E, Makler V, Bauer DF. Vagal Nerve Stimulator Malfunction with Change in Neck Position: Case Report and Literature Review. World Neurosurg 2018;114:165-7. [CrossRef]

21. Giordano F, Zicca A, Barba C, Guerrini R, Genitori L. Vagus nerve stimulation: Surgical technique of implantation and revision and related morbidity. Epilepsia 2017;58:85-90. [CrossRef]

22. Aalbers MW, Rijkers K, Klinkenberg S, Majoie M, Cornips EM. Vagus nerve stimulation lead removal or replacement: surgical technique, institutional experience, and literature overview. Acta Neurochir (Wien) 2015;157(11):1917-24. [CrossRef]

23. Magney JE, Flynn DM, Parsons JA, Staplin DH, Chin-Purcell MV, Milstein S, Hunter DW. et al. Anatomical mechanisms explaining damage to pacemaker leads, defibrillator leads, and failure of central venous catheters adjacent to the sternoclavicular joint. Pacing Clin Electrophysiol 1993;16(3-1):445-57. [CrossRef]

24. Espinosa J, Aiello MT, Naritoku DK. Revision and removal of stimulating electrodes following long-term therapy with the vagus nerve stimulator. Surg Neurol 1999;51(6):659-64. [CrossRef]

25. MacDonald J, Couldwell WT. Revision of vagal nerve stimulator electrodes: technical approach. Acta Neurochir (Wien) 2004;146(6):567-70. [CrossRef]

26. Couch JD, Gilman AM, Doyle WK. Long-term Expectations of Vagus Nerve Stimulation: A Look at Battery Replacement and Revision Surgery. Neurosurgery 2016;78(1):42-6. [CrossRef] 